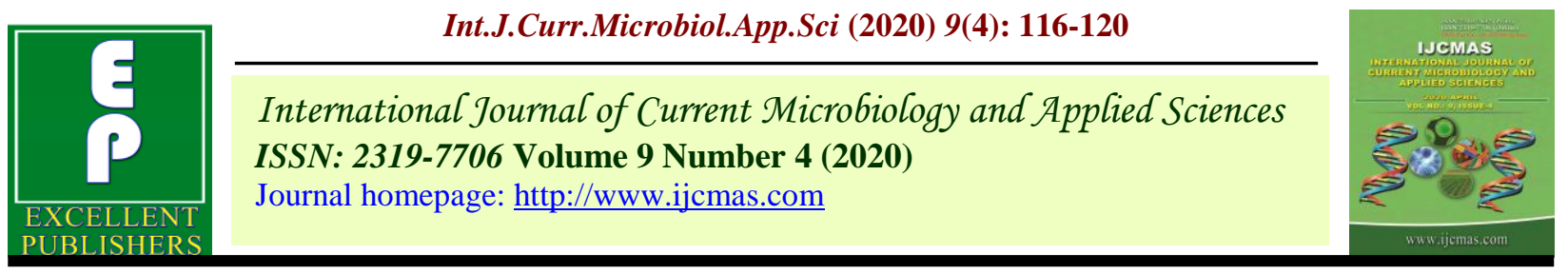

Original Research Article

https://doi.org/10.20546/ijcmas.2020.904.015

\title{
Influence of Application of Seri-Waste Bio-Digester Liquid to Mulberry on Cocoon Parameters of Silkworm, Bombyx mori L.
}

\author{
Potala Harshita Mala* and S. Chandrashekhar \\ Department of Sericulture, College of Agriculture, University of Agricultural Sciences, \\ GKVK, Bengaluru - 560 065, India \\ *Corresponding author
}

Keywords

Mulberry, Seri waste biodigester,

Silkworm, Rearing performance

Article Info

Accepted:

04 March 2020

Available Online:

10 April 2020

\section{A B S T R A C T}

An experiment was conducted during 2017-18 to study the effect of seriwaste bio-digester application to mulberry on cocoon parameters of silkworm. Mulberry grown with the application of 50 per cent seri-biodigester effluent +25 per cent bio-digester effluent +25 per cent Recommended Dose of Fertilizers (RDF) significantly enhanced the Effective Rate of Rearing (ERR) (98.28 per cent), maximum larval weight $(38.63 \mathrm{~g} / 10)$ and cocoon parameters viz., single cocoon weight $(1.86 \mathrm{~g})$, pupal weight $(1.53 \mathrm{~g})$, shell weight $(0.30 \mathrm{~g})$, shell ratio $(16.60$ per cent) and single cocoon filament length $(915.10 \mathrm{~g})$ followed by 25 per cent seri-biodigester effluent +25 per cent bio-digester effluent +25 per cent vermi compost +25 percent compost with larval weight $(1.86 \mathrm{~g})$, pupal weight $(1.53 \mathrm{~g})$, shell weight $(1.53 \mathrm{~g})$, shell ratio (16.34 per cent) and single filament length $(911.68 \mathrm{~m})$. The study revealed that, application of seriwaste bio-digester effluent to mulberry along with other organic manures increased the rearing and cocoon parameters providing all the essential nutrients for mulberry growth compared to application of sole inorganic fertilizers and in turn it contributed for quality cocoon production. Utilization of sericulture waste generated during mulberry cultivation and silkworm rearing leads to generate additional income, entrepreneurship development in sericulture and value addition in turn contributing to achieve sustainability in sericulture.

\section{Introduction}

The monophagous silkworm, Bombyx mori L. feeds only on mulberry leaves. A large quantity of sericulture waste from silkworm rearing units is coming out in the form of silkworm faeces (litter) and leftover food material of silkworms which is creating 
environmental problems. It was estimated that, by rearing 100 dfls (disease free layings') consuming $1000 \mathrm{~kg}$ of mulberry leaves, approximately $300 \mathrm{~kg}$ of litter and $500 \mathrm{~kg}$ of unused (leftover) mulberry waste comprising of dried leaves, veins of leaves, leaf stalks etc., are generated.

On the basis of availability of sericulture waste mainly in sericulture areas, this waste has been tried as substrate for mushroom cultivation and biogas production. After biogas generation, the left over slurry containing the supernatant effluent is known to have lot of manurial value. Hence, the mulberry sericulture waste bio-digester liquidhas been applied to mulberry to study its impact on growth and yield and also quality of mulberry leaf and inturn its effect on the performance of the silkworm Bombyx mori L.

\section{Materials and Methods}

An experiment was conducted during Kharif season of 2017-18 to study the effect of seriwaste bio-digester application to mulberry on cocoon parameters of silkworm. After imposition of 11 treatments (Table $1 \& 2$ ) to mulberry garden. The silkworm rearing was taken to know the response of silkworm to mulberry grown with the application of different manures.

The mulberry leaves harvested from different treatments were fed to the respective batch of silkworms. The young silkworms were reared in plastic trays by feeding thrice a day with chopped tender mulberry leaves of $V_{1}$ variety. Normal rearing was conducted upto fourth instar of silkworm by following standard rearing practices (Dandin et al., 2001).Observations were recorded on rearing performance of silkworm (Table 1) and cocoon and also post reeling parameters (Table 2).

\section{Results and Discussion}

Application of seri waste biodigester liquid to mulberry soil to supply major and micro nutrients along with inorganic fertilizers had significant influence on ERR of hybrid silkworm PM $\times$ CSR2 (Table 1).

However, marked increase in ERR (98.28 per cent) was noticed in worms which were fed with leaf corresponding to 50 per cent Seri Bio-digester effluent +25 per cent Biodigester effluent +25 per cent RDF and it was on par with 25 per cent Seri Bio-digester effluent +25 per cent Bio-digester effluent + 25 per cent Vermicompost +25 per cent Compost (98.17 per cent) and 50 per cent Seri Bio-digester effluent +25 per cent Compost + 25 per cent RDF (98.02 per cent). Lower ERR (89.32 per cent) was recorded in respect of 100 per cent Recommended dose of fertilizers. Increase in ERR might be due to feeding of nutritionally superior quality mulberry leaves to silkworms. Mulberry raised with application of higher dose of organic manures with lower dose of inorganic fertilizers fed to worms have recorded higher ERR with good quality cocoons (Philomena et al., 2003). Maximum full grown larval weight $(38.84 \mathrm{~g} / 10$ larvae) was observed when silkworms were raised on mulberry leaves grown with the application of 50 per cent Seri Bio-digester effluent +25 per cent Biodigester effluent +25 per cent RDF and 25 per cent Seri Bio-digester effluent +25 per cent Bio-digester effluent +25 per cent Vermicompost +25 per cent compost (37.29 $\mathrm{g} / 10$ worms) compared to other treatments (Table 1). The lowest larval weight (34.32 $\mathrm{g} / 10$ larvae) was noticed in 100 per cent RDF. Increase in larval weight might be due to the resultant superior leaf quality. Shankar (1990) too observed that, application of nutrients in different forms of organic sources to mulberry resulted in superior maximum larval weight than applying inorganic fertilizers alone. 
Table.1 Influence of feeding V1 mulberry leaf obtained through application of seri waste biodigester on effective rate of rearing and larval weight of PM $\times$ CSR2 hybrid

\begin{tabular}{|c|c|c|}
\hline Treatments & $\begin{array}{c}\text { Effective rate of rearing } \\
\text { (ERR } \\
\text { per cent) }\end{array}$ & $\begin{array}{c}\text { Maximum larval } \\
\text { weight } \\
\text { (g/10 larvae) }\end{array}$ \\
\hline 100\% Recommended Dose of Fertilizers (RDF) & $\begin{array}{l}89.32^{\mathrm{a}} \\
(9.48)\end{array}$ & $34.31^{\mathrm{a}}$ \\
\hline $75 \%$ Seri Bio-digester effluent+ $25 \%$ RDF & $\begin{array}{l}96.75^{\mathrm{e}} \\
(9.86)\end{array}$ & $36.9^{\mathrm{g}}$ \\
\hline $50 \%$ Seri Bio-digester effluent $+25 \%$ Compost $+25 \%$ RDF & $\begin{array}{l}98.02^{f} \\
(9.93)\end{array}$ & $36.90^{\mathbf{g}}$ \\
\hline $50 \%$ Seri Bio-digester effluent+25\% Bio-digester effluent + 25\% RDF & $\begin{array}{l}98.28^{f} \\
(9.94)\end{array}$ & $38.63^{i}$ \\
\hline $\begin{array}{l}25 \% \text { Seri Bio-digester effluent }+25 \% \text { Bio-digester } \\
\text { effluent }+25 \% \text { Vermicompost }+25 \% \text { Compost }\end{array}$ & $\begin{array}{l}98.17^{\mathbf{f}} \\
(9.93)\end{array}$ & $37.38^{\mathrm{h}}$ \\
\hline $75 \%$ Seri Bio-digester effluent $+25 \%$ Vermicompost & $\begin{array}{l}96.7^{\mathrm{e}} \\
(9.86)\end{array}$ & $36.50^{\mathrm{f}}$ \\
\hline $50 \%$ Compost $+50 \%$ Seri bio-digester effluent & $\begin{array}{l}94.32^{d} \\
(9.74)\end{array}$ & $36.38^{\mathrm{f}}$ \\
\hline $100 \%$ Vermicompost & $\begin{array}{l}92.31^{\mathbf{b}} \\
(9.63)\end{array}$ & $34.92^{\mathbf{b}}$ \\
\hline 100\% Bio-digester effluent & $\begin{array}{l}93.46^{c} \\
(9.69)\end{array}$ & $35.54^{\mathrm{d}}$ \\
\hline $100 \%$ Compost & $\begin{array}{l}93.08^{\mathbf{c}} \\
(9.67)\end{array}$ & $35.29^{c}$ \\
\hline $100 \%$ Seri Bio-digester effluent & $\begin{array}{l}94.01^{d} \\
(9.72)\end{array}$ & $36.15^{\mathrm{e}}$ \\
\hline S.Em \pm & 0.247 & 0.051 \\
\hline C.D@ 5\% & 0.724 & 0.149 \\
\hline
\end{tabular}


Table.2 Feeding influence of V1 mulberry leaf obtained through application of seri waste biodigester on cocoon parameters of silkworm hybrid, PM $\times$ CSR2

\begin{tabular}{|c|c|c|c|c|c|}
\hline Treatments & $\begin{array}{l}\text { Single cocoon } \\
\text { weight }(g)\end{array}$ & $\begin{array}{l}\text { Pupal weight } \\
\text { (g) }\end{array}$ & $\begin{array}{c}\text { Shell } \\
\text { weight (g) }\end{array}$ & $\begin{array}{l}\text { Shell ratio } \\
(\%)\end{array}$ & $\begin{array}{l}\text { Single cocoon filament } \\
\text { length }(\mathrm{m})\end{array}$ \\
\hline $100 \%$ Recommended Dose of Fertilizers (RDF) & $1.65^{\mathrm{a}}$ & $1.28^{\mathrm{a}}$ & $0.24^{\mathrm{a}}$ & $\begin{array}{l}14.52^{\mathrm{a}} \\
(3.88)\end{array}$ & $849.91^{\mathrm{a}}$ \\
\hline $75 \%$ Seri Bio-digester effluent+ $25 \%$ RDF & $1.81^{\mathrm{e}}$ & $1.52^{\mathrm{e}}$ & $0.29^{\mathrm{e}}$ & $\begin{array}{l}15.92^{b} \\
(4.05)\end{array}$ & $904.34^{\mathrm{f}}$ \\
\hline $\begin{array}{l}50 \% \text { Seri Bio-digester effluent }+25 \% \text { Compost }+25 \% \\
\text { RDF }\end{array}$ & $1.84^{\mathrm{f}}$ & $1.52^{\mathrm{e}}$ & $0.3^{\mathbf{f}}$ & $\begin{array}{l}16.28^{c} \\
(4.10)\end{array}$ & $904.34^{\mathrm{f}}$ \\
\hline $\begin{array}{l}50 \% \text { Seri Bio-digester effluent+25\%Bio-digester effluent } \\
+25 \% \text { RDF }\end{array}$ & $1.86^{\mathbf{f}}$ & $1.53^{\mathrm{e}}$ & $0.3^{\mathbf{f}}$ & $\begin{array}{l}16.60^{c} \\
(4.14)\end{array}$ & $915.1^{\mathrm{h}}$ \\
\hline $\begin{array}{l}25 \% \text { Seri Bio-digester effluent }+25 \% \text { Bio-digester } \\
\text { effluent }+25 \% \text { Vermicompost }+25 \% \text { Compost }\end{array}$ & $1.86^{\mathrm{f}}$ & $1.53^{\mathrm{e}}$ & $0.3^{\mathrm{f}}$ & $\begin{array}{l}16.34^{\mathrm{c}} \\
(4.10)\end{array}$ & $911.68^{\mathrm{g}}$ \\
\hline $75 \%$ Seri Bio-digester effluent $+25 \%$ Vermicompost & $1.8^{\mathrm{d}}$ & $1.51^{\mathrm{e}}$ & $0.28^{\mathrm{e}}$ & $\begin{array}{l}15.91^{b} \\
(4.05)\end{array}$ & $886.05^{\mathrm{e}}$ \\
\hline $50 \%$ Compost $+50 \%$ Seri bio-digester effluent & $1.79^{d}$ & $1.48^{\mathrm{d}}$ & $0.28^{\mathrm{e}}$ & $\begin{array}{l}15.44^{\mathbf{b}} \\
(3.99)\end{array}$ & $882.33^{d}$ \\
\hline $100 \%$ Vermicompost & $1.68^{\mathbf{b}}$ & $1.4^{\mathrm{b}}$ & $0.25^{\mathbf{b}}$ & $\begin{array}{l}14.71^{\mathbf{a}} \\
(3.90)\end{array}$ & $873.75^{b}$ \\
\hline $100 \%$ Bio-digester effluent & $1.73^{\mathrm{c}}$ & $1.43^{\mathrm{c}}$ & $0.27^{d}$ & $\begin{array}{l}14.95^{\mathrm{a}} \\
(3.39)\end{array}$ & $878^{c}$ \\
\hline $100 \%$ Compost & $1.72^{\mathrm{c}}$ & $1.43^{\mathrm{c}}$ & $0.26^{\mathrm{c}}$ & $\begin{array}{l}14.79^{\mathrm{a}} \\
(3.91)\end{array}$ & $885.6^{\mathrm{e}}$ \\
\hline $100 \%$ Seri Bio-digester effluent & $1.78^{d}$ & $1.47^{\mathrm{d}}$ & $0.27^{\mathrm{d}}$ & $\begin{array}{l}15.14^{\mathbf{a}} \\
(3.95)\end{array}$ & $880.39^{d}$ \\
\hline F- test & $*$ & $*$ & $*$ & $*$ & $*$ \\
\hline S.Em \pm & 0.007 & 0.008 & 0.004 & 0.228 & 0.740 \\
\hline C.D@ 5\% & 0.021 & 0.025 & 0.012 & 0.668 & 2.170 \\
\hline
\end{tabular}


Application of seribiodigester along with biodigester liquid and recommended dose of fertilizers registered marked influence on cocoon traits (Table 2). Cocoon weight (1.86g), pupal weight $(1.53 \mathrm{~g})$, shell weight $(0.30 \mathrm{~g})$, shell ratio (16.60 per cent) and single cocoon filament length $(925.10 \mathrm{~m})$ were maximum in worms fed with mulberry leaf raised with 50 per cent Seri Bio-digester effluent +25 per cent Bio-digester effluent +25 per cent RDF followed by that of 25 per cent Seri Bio-digester effluent +25 per cent Bio-digester effluent +25 per cent Vermicompost +25 per cent Compost (1.85g of cocoon weight, $1.53 \mathrm{~g}$ of pupal weight, $0.30 \mathrm{~g}$ of shell weight, 16.34 per cent of shell ratio, $311.68 \mathrm{~m}$ of single cocoon filament length) and of 50 per cent Seri Bio-digester effluent + 25 per cent Compost +25 per cent RDF $(1.85 \mathrm{~g}$ of cocoon weight, $1.52 \mathrm{~g}$ of pupal weight, 0.30 $\mathrm{g}$ of shell weight, 16.28 per cent of shell ratio, $904.34 \mathrm{~m}$ of single filament length). The lower cocoon traits were noticed in respect of 100 per cent Recommended dose of fertilizers cocoon weight $(1.66 \mathrm{~g})$, pupal weight $(1.28 \mathrm{~g})$, shell weight $(0.24 \mathrm{~g})$, shell ratio (14.52 per cent) and single filament length $(849.91 \mathrm{~m})$. Increase in cocoon parameters might be due to high organic matter in soil, good water holding capacity and adequate nutrient availability leading to better soil characteristics which in turn supported for quality mulberry leaves and thereby quality cocoons. The seri waste biodigester liquid might have supplied all the essential components required for the plant which helped in better performance of silkworms and cocoon quantitative traits.

In conclusion, the present study showed that, the highest cocoon parameters viz., cocoon weight, pupal weight, shell weight, shell ratio and single cocoon filament length were recorded in worms fed with V1 mulberry leaf obtained through application of 50\% seri waste biodigester $+25 \%$ bio-digester effluent $+25 \%$ RDF.

\section{References}

Dandin, B. S., Jayaswal, J. and Giridhar, K., 2001, Handbook of Sericulture Technologies. Central Silk Board, Bangalore. P. 287.

Murali, C., Sreeramulu, K. R., Narayanaswamy, T. K., Shankar, M. A. and Amarnath, N., 2006. Effect of bioinoculants and organic manures on the yield and quality of S36 mulberry. Natl. Sem. Soil Health and Water Management for Sustainable Sericulture, $27^{\text {th }}$ and $28^{\text {th }}$ September, Regional Sericultural Research Station (A unit of CSB), Bangalore-India, p.90.

Narayanaswamy, T. K., Rajegowda, Shankar, M. A. and Sreeramulu, K. R.,2006, Effect of different organic manures on growth and yield parameters of M5 and S36 mulberry varieties in relation to silkworm growth. Research on Crops, 7(2): 541-543.

Philomena, K. L., Subramanayam, M. R., Jagadeesh, N. and Kamble, C. K., 2003, Qualitative and quantitative analysis of varieties as influenced by using organic manure (compost) and inorganic fertilizers for production of quality seed cocoons. Proc. Natl. Sem. Silkworm Seed Prodn., SSTL, Bangalore, pp.69-74.

Phiny, C., Borin, K., Preston, T. R. and TY, C., 2009, Effect of level of effluent from biodigesters loaded with pig manure on the growth of mulberry (Morus alba L.) trees. Livestock Research for Rural Development, 21(7): 114

Shankar, M. A., 1990, Nutritional management of mulberry and its effect on silkworm growth, development and silk quality. $P h$. D. (Agronomy) Thesis, Univ. Agric. Sci., Bengaluru, Karnataka, India, p.410.

\section{How to cite this article:}

Potala Harshita Mala and Chandrashekhar, S. 2020. Influence of Application of Seri-Waste Bio-Digester Liquid to Mulberry on Cocoon Parameters of Silkworm, Bombyx mori L. Int.J.Curr.Microbiol.App.Sci. 9(04): 116-120. doi: https://doi.org/10.20546/ijcmas.2020.904.015 